This is a pre-copyedited, author-produced version of an article by Ben Christman and

Malcolm M. Combe accepted for publication in the January 2020 issue of the Edinburgh Law

Review.

\title{
Funding civil justice in Scotland: full cost recovery, at what cost to justice?
}

\section{A. INTRODUCTION}

There are costs associated with the administration of a civil justice system. How should those costs be met? That is an important question for all legal systems. In Scotland, it is one that successive Scottish Governments have answered by finding ways for those costs to be met by the users of the court system. Such a policy can broadly be referred to as "full cost recovery".

A recent consultation, which closed on 12 January 2018, sought views on the level of court fees in Scotland until 2021. It did so without stress-testing the overall policy of full cost recovery, but various consultees nevertheless took the opportunity to comment. Amongst the 22 responses to this consultation was a response from the Access to Justice Committee of the Law Society of Scotland. ${ }^{1}$ Before going on to consider the individual points raised in the consultation, that Committee - which both authors of this article are members of - reiterated its resistance to any moves towards full cost recovery (having also made the point in 2016). The Committee noted: "A properly funded court system is an essential part of our civilised society and respect for the rule of law, and it is in the public interest to maintain a robust and respected system for resolving disputes. It is the proper responsibility of the state to fund that system.”

With the consultation now closed, the Scottish Government response to that exercise available, and the court fees in subsequent Orders expected to run until 31 March 2021, it might be thought that it is rather late to analyse all of this, but whilst one consultation exercise has closed another will come around soon enough: some point in 2020 being the expected moment. ${ }^{2}$ This analysis should also be of interest to non-Scottish readers who may be contending with a similar challenge in another jurisdiction.

With that in mind, this article aims to inform any future Scottish consultation exercise, by critiquing full cost recovery in principle and by offering potential routes by which its implementation might be challenged. It will begin by explaining what full cost recovery actually is and investigating its origins, before interrogating some of the assumptions or acquiescence that seems to have developed around the issue and discussing the potential for litigation against court fees in Scotland.

\footnotetext{
${ }^{1}$ Available at https://www.lawscot.org.uk/media/359439/atj-consultation-on-scottish-court-fees-2018-2021.pdf . The Faculty of Advocates also opposed the increase: see R Jackson, The Scotsman 10 January 2018 "Lawyers warn Scotland's court fees scheme 'could be illegal'” at https://www.scotsman.com/news/lawyers-warnscotland-s-court-fees-scheme-could-be-illegal-1-4657955.

${ }^{2}$ Scottish Court Fees 2018-2021: consultation analysis and Scottish Government response (2018) para 81, available at https://www.gov.scot/publications/scottish-court-fees-2018-2021-analysis-consultation-scottishgovernment-response/pages/0/.
} 


\section{B. COURT FEES, AND THE ORIGINS OF FULL COST RECOVERY}

A critical question for those interested in civil justice is not 'what rights do we give?', but having given those rights... what opportunities and structures do we provide for the public to enforce those rights and obligations or make good their entitlements? ${ }^{3}$

Undergirding much of the discussion in this paper is the notion of access to justice. It will be analysed in more detail below. It is important to state at the outset though that the meeting of costs involved in bringing legal proceedings - which forms an inevitable part of a transition to full cost recovery - is part of the access to justice mix. In simple terms, any increase in costs for a potential litigant will have an impact on those users who struggle to afford whatever those costs might be; much like the economic concept of price elasticity, stretching a fee to a higher level will (eventually) have an impact on how many people are able or willing to pay that fee.

For context, here is a snapshot of fee levels as at 1 April 2019 working through the court hierarchy. In the Sheriff Court, the default for raising proceedings is $£ 129$ unless another sum is specified, with a summary cause/simple procedure costing £104 to raise (or, for an action worth less than £300, only £19) and other particular procedures having set fees, and thereafter the defender may have to pay to respond (the corresponding default sum being £129) and then further costs may accrue depending on how the case develops. ${ }^{4}$ For each day or part thereof of proof, debate or hearing in a summary or miscellaneous application on the merits of the cause there is a fee of £232. In the Sheriff Appeal Court, daily hearing fees for a bench of one are $£ 237$ (and $£ 593$ for a bench of three). ${ }^{5}$ A Court of Session hearing (during the normal working day) before a bench of one or two judges is $£ 209$ payable by each party for every 30 minutes or part thereof (albeit the first 30 minutes of the hearing of a motion is free). ${ }^{6}$ Fees in all three courts will increase again on 1 April 2020.

Granted, there are some things that need to be considered alongside court fees. First, the general

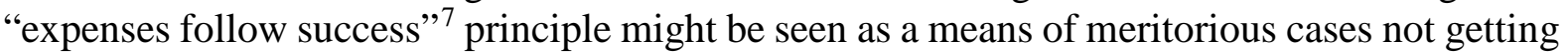
sifted at an early stage. As was noted by a respondent quoted in the Taylor Review, ${ }^{8}$ however, such an analysis is a tad simplistic, as there can be a disparity between actual expenses incurred and the level of recovery, not to mention the fact that an expenses award might come much later than an initial outlay. Even with innovations that might allow some flavours of litigation to proceed, such as qualified one-way cost shifting for personal injury cases, ${ }^{9}$ many cases can still be discouraged by high fees.

Legal aid - another important feature in the access to justice mix which will be analysed in more detail below - offers a safety net for some, but there is an increasingly squeezed middle of those who are ineligible for support but unable to afford the costs associated with litigation, leaving a corresponding void in cases that are brought. ${ }^{10}$ And whilst the expense of court might

\footnotetext{
${ }^{3}$ H Genn, Judging Civil Justice (2010) 11.

${ }^{4}$ The Sheriff Court Fees Order 2018 (SSI 2018/81), as amended by the Sheriff Court Fees Amendment Order 2018 (SSI 2018/194).

5 The Sheriff Appeal Court Fees Order 2018 (SSI 2018/82).

6 The Court of Session etc. Fees Order 2018 (SSI 2018/83).

${ }^{7}$ Consider Ashiq $v$ Secretary of State for Home Dept [2016] CSIH 1 as a recent example of its application.

8 Sheriff J A Taylor, Report of the Review of Expenses and Funding of Civil Litigation in Scotland (2013) ch 2, para 6, at https://www2.gov.scot/Resource/0043/00438205.pdf.

${ }^{9}$ Civil Litigation (Expenses and Group Proceedings) (Scotland) Act s 8.

${ }^{10}$ Consider C McCorkindale, “The New Powers of the Judiciary in Scotland - Part I” Judicial Power Project (2016) where he notes "challenges are typically raised by those with the greatest resources (e.g. insurance,
} 
encourage or indeed force some people towards alternative dispute resolution mechanisms, even a recent Scottish Parliament Committee Report entitled I won't see you in court: alternative dispute resolution in Scotland noted that "in some cases going to court may be the most appropriate form of dispute resolution and parties should remain free to choose that option if they so wish." 11 The "free" in that quote is presumably to be construed as "available". As we shall see, choosing - if that is the correct word - the "option" of court is not free for many.

This paper will not bring fresh empirical analysis into the impact that fees or indeed other litigation-related outlays and non-financial hurdles may have on people who find themselves facing a legal problem. ${ }^{12}$ It will however bring some analysis of what hampering access to court might mean when it comes to establishing useful precedent (albeit that might be taken as something of a given in the aftermath of the important UK Supreme Court decision of $R$ (on the application of UNISON) $v$ Lord Chancellor), ${ }^{13}$ and, most importantly, it will target and test some of the assumptions about fees and the justifications for full cost recovery that have been made. Before doing so, we explain how Scotland has reached the current position.

\section{(1) Powers to set court fees}

From the late $19^{\text {th }}$ century until the early 1980s, fees in the Court of Session and Sheriff Court were set using powers in the Courts of Law (Fees) (Scotland) Act 1895 and the Sheriff Courts (Scotland) Act 1907 respectively. The powers to set court fees in both Acts was exercised by the Court of Session, acting with the approval of the Commissioners of Her Majesty's Treasury. ${ }^{14}$

This changed with the introduction of the Divorce Jurisdiction, Court Fees and Legal Aid (Scotland) Act 1983. This transferred the power to set court fees to the Secretary of State for Scotland, ${ }^{15}$ reassigning the power to set court fees from the Judiciary to the Executive.

The power to set fees was then transferred to the Scottish Ministers under the Scotland Act 1998. ${ }^{16}$ Following this, the Courts Reform (Scotland) Act 2014 clarified that the power to set court fees is the exclusive domain of the Scottish Ministers. ${ }^{17}$ Under the 2014 Act, the Scottish Ministers have the power to make provision for the charging of fees in respect of the carrying out of the functions of the Scottish Courts and Tribunals Service by way of order.

\footnotetext{
alcohol and tobacco companies, wealthy landowners or well-funded interest groups) or by those with the least (for example, by prisoners who are able to access legal aid)", at https://judicialpowerproject.org.uk/the-newpowers-of-the-judiciary-in-scotland/, linking there to five cases brought by those with the greatest resources and one brought by prisoners with nothing to lose. This is discussed further below.

${ }^{11}$ Justice Committee, SP Paper 381 9th Report, 2018 (Session 5) para 122. See also T Bingham, The Rule of Law (2011) 86. On the Justice Committee Report, see further B Clark, “Some reflections on 'I won't see you in court"” 2019 Jur. Rev. 182. Incidentally, immediately prior to the extracted quote it was noted that the Committee agreed with the majority of the evidence before it that people should not be compelled to participate in alternative dispute resolution. Without wishing to oversimplify, if someone is not to be compelled towards ADR but court is too expensive, what is someone with a genuine dispute supposed to do?

${ }^{12}$ See H Genn and A Paterson, Paths to Justice Scotland: What people in Scotland do and think about going to law (2001).

${ }^{13}$ [2017] UKSC 51, para 69-73. See further E Rose, " $R$ (on the application of UNISON) v Lord Chancellor: A masterclass in the constitutional right of access to the courts” 2017 Jur. Rev. 261.

${ }^{14}$ Courts of Law (Fees) (Scotland) Act 1895 s 2 and Sheriff Courts (Scotland) Act 1907 s 40.

${ }^{15}$ Divorce Jurisdiction, Court Fees and Legal Aid (Scotland) Act 1983 s 4 - which amended s 2 of the Courts of Law (Fees) (Scotland) Act 1895.

${ }^{16} \mathrm{~S} 53$.

${ }^{17} \mathrm{~S} 107$.
} 
In respect of civil cases which reach the UK Supreme Court from Scotland, the Constitutional Reform Act 2005 provides that the Lord Chancellor can prescribe fees by order. ${ }^{18}$ This power is to be exercised after consultation with the Lord President of the Court of Session, the Faculty of Advocates and the Law Society of Scotland (amongst other bodies from elsewhere in the UK). ${ }^{19}$ When exercising this power, the Lord Chancellor must have regard to the principle that access to the courts must not be denied. ${ }^{20}$

\section{(2) Court fees pre-devolution}

Full cost recovery (FCR) - the policy that the costs of the civil justice system should be funded directly by its litigants, rather than it being paid out of general taxation - pre-dates devolved government in Scotland. Prior to devolution, the UK Government's policy had been to increase civil court fees up to the point of FCR. ${ }^{21}$

Stephenson has remarked that the legislative history of court fees in Scotland was largely static from the early $20^{\text {th }}$ century until the 1980 s. $^{22}$ The Civil Justice Council has noted that the development of FCR is a relatively recent one - and prior to the 1980s, two UK Government papers had addressed the issue in detail. ${ }^{23}$ First, in a 1923 report on court fees, a committee appointed by the Lord Chancellor found that:

We understand that in the opinion of the Treasury the balance between expenditure and revenue of the County Courts should be adjusted on the basis that the State should bear the cost of the Court buildings and the salaries, pensions, and travelling expenses of the Judges, and that the rest of the expenditure should be defrayed by the suitors' fees. ${ }^{24}$

The issue of fees appears not to have surfaced again until the 1980s. The Twelfth Report for the Committee of Public Accounts for the 1981-1982 session noted that the Treasury's view on the matter had changed, that the policy was under review and some form of cost recovery would be sought. ${ }^{25}$

Then - in the Government's Expenditure Plans 1983-84 to 1985-86 - it was stated that, "for the Civil Courts, the plans take account of the agreed policy to recover full costs less judicial costs through court fees". ${ }^{26}$ In the assessment of the Civil Justice Council, this meant that, "apparently without any formal announcement or debate in Parliament, it had been decided that accommodation costs should be borne by litigants”. ${ }^{27}$

\footnotetext{
18 S 52.

${ }^{19} \mathrm{~S} 52(4-6)$.

${ }^{20} \mathrm{~S}$ 52(3).

${ }^{21}$ Scottish Executive, Civil court fees in the Court of Session and the Sheriff Court: a consultation paper (2001), para 1.

${ }^{22}$ Andrew Stephenson, “Court fees: an increased risk for practitioners” Civil Practice Bulletin (2017).

${ }^{23}$ Civil Justice Council, "Full costs recovery: a paper by the fees sub-committee” (2002) 4-6.

${ }^{24}$ Report of the Committee to Consider court fees (1923, Cmd. 1856), para 6 - quoted in Civil Justice Council, "Full costs recovery" 4.

${ }^{25}$ Civil Justice Council "Full costs recovery” 4-5.

${ }^{26}$ The UK Government’s Expenditure Plans 1983-84 to 1985-86 (Vol II) 42 - quoted in Civil Justice Council, 'Full costs recovery' 5.

27 Para 2.6.
} 
Almost immediately prior to devolution, further developments confirmed the UK Government's intention to pursue FCR. The Lord Chancellor Lord Irvine reaffirmed the Government's commitment to FCR in a debate on civil court fees in the House of Lords in July 1997. ${ }^{28}$ A September 1997 report by on civil justice and legal aid found that:

One of the most important signals in any system is price. If prices do not fully reflect costs, it is not possible for users to make sound choices about the appropriate way to pursue their problem...There is no justification for setting fees generally at levels that do not reflect cost. ${ }^{29}$

A 1998 discussion paper then issued by the UK Department for Constitutional Affairs then proposed further amendments to FCR, including that fees be charged in advance rather than in arrears. $^{30}$

\section{(3) Court fees post-devolution}

The power to set fees was transferred to the Scottish Ministers by the Scotland Act 1998. Postdevolution, an alternative approach could have been adopted. Yet devolution saw the continuation and entrenchment of FCR in Scotland.

On carrying out the first post-devolution review of the policy of FCR, the then 2001 Scottish Executive consultation paper noted that:

Scottish Ministers have reviewed the policy that was inherited from their predecessors. Their view is that there should continue to be a move in the direction of full cost recovery. ${ }^{31}$

Scottish Governments of various political compositions have since demonstrated their commitment to FCR. The post-devolution history of court fees is one of a stream of consultation documents and statutory instruments which have gradually increased court fees towards a position of FCR.

\footnotetext{
${ }^{28}$ The Lord Chancellor, Lord Irvine, reaffirmed that "the present principle is to recover the full cost of providing the civil courts, less an amount equivalent to the sum of exemptions and remissions", 14 July 1997 (Hansard, col 863ff).

${ }^{29}$ Peter Middleton, Report to the Lord Chancellor (UK Department for Constitutional Affairs, 1997), paras 5.21 and 5.22 .

${ }^{30}$ UK Department for Constitutional Affairs, Access to Justice - Civil Fees: A Lord Chancellor's Department Discussion Paper (1998).

${ }^{31}$ Scottish Executive, Civil court fees in the Court of Session and the Sheriff Court: a consultation paper (2001), para 2.
} 
Eight rounds of court fee amendments have occurred post-devolution. Successive fee increases have been made by Scottish statutory instruments in 2002, ${ }^{32} 2007,{ }^{33} 2008,{ }^{34} 2009,{ }^{35} 2012,{ }^{36}$ $2015,{ }^{37} 2016^{38}$ and 2018. ${ }^{39}$

To understand the effect of the policy of FCR in Scotland, it is helpful to examine the changes that these orders have made to the fees charged to litigants. In the 1999 (pre-devolution) fee order, the fee payable in the Court of Session per half hour of hearing time was $£ 13$ for a single judge hearing in the Outer House and $£ 26$ per half hour in the Inner House. ${ }^{40}$ The equivalent fees are now £209 and $£ 522$ per half hour respectively. ${ }^{41}$ In the Sheriff Court, the fee payable per each day (or part thereof) of a proof, debate or hearing in a summary or miscellaneous application on the merits of the cause in the 1999 fee order was $£ 58 .{ }^{42}$ The equivalent fee is now £237. ${ }^{43}$

\section{(4) FCR policy themes post-devolution}

Scottish Governments' policies on court fees (as evidenced by the consultation documents which preceded each round of statutory instruments) have displayed three common themes.

First, the preference for FCR is framed around the need to remove the "subsidy" which the general taxpayer has provided to resolving civil disputes. ${ }^{44}$ This view is predicated on the understanding that the civil courts provide a private dispute resolution service - the benefits of which are accrued by the parties directly involved in civil litigation. This is clearly articulated in the 2015 consultation paper, which justifies FCR in the following terms:

Where a dispute is between two private individuals, the policy position taken by the Government is that the majority of the benefits of resolving that dispute are expected to flow to the parties rather than to the state. Therefore, it is unreasonable to ask taxpayers

\footnotetext{
32 The Court of Session Fees Amendment Order 2002 (SSI 2002/270) and the Sheriff Court Fees Amendment Order 2002 (SSI 2002/269).

33 The Sheriff Court Fees Amendment Order 2007 (SSI 2007/318) and the Court of Session etc. Fees Amendment Order 2007 (SSI 2007/319).

34 The Court of Session etc. Fees Amendment Order 2008 (SSI 2008/236), the Sheriff Court Fees Amendment Order 2008 (SSI 2008/237) and the Lyon Court and Office Fees (Variation) (No. 2) Order 2008 (SSI 2008/168).

35 The Court of Session etc. Fees Amendment Order 2009 (SSI 2009/88) and the Sheriff Court Fees Amendment Order 2009 (SSI 2009/89).

36 The Court of Session etc. Fees Amendment Order 2012 (SSI 2012/290) and the Sheriff Court Fees Amendment Order 2012 (SSI 2012/293).

${ }^{37}$ The Adults with Incapacity (Public Guardian's Fees) (Scotland) Regulations 2015 (SSI 2015/260), the Court of Session etc. Fees Order 2015 (SSI 2015/261), the Sheriff Court Fees Order 2015 (SSI 2015/264) and the Sheriff Appeal Court Fees Order 2015 (SSI 2015/379).

38 The Court Fees (Miscellaneous Amendments) (Scotland) Order 2016 (SSI 2016/332) and the Lyon Court and Office Fees (Variation) (Devolved Functions) Order 2016 (SSI 2016/390).

39 The Sheriff Court Fees Order 2018 (SSI 2018/81), the Sheriff Appeal Court Fees Order 2018 (SSI 2018/82), the Court of Session etc. Fees Order 2018 (SSI 2018/83) and the Sheriff Court Fees Amendment Order 2018 (SSI 2018/194).

40 The Court of Session etc. Fees Amendment Order 1999 (SI 1999/755), Schedule 2, Part I, B19 and B20.

${ }^{41}$ SSI 2018/83, Schedule 1, Part I, B16 and B17.

42 The Sheriff Court Fees Amendment Order 1999, (SI 1999/754), Schedule, Part II, para 25.

43 The Sheriff Court Fees Order 2018 (SSI 2018/81), Schedule 2, Part 1, para 27.

${ }^{44}$ Scottish Executive, Civil court fees in the Court of Session and the Sheriff Court: a consultation paper (2001), para 1 and the Scottish Court Service, Consultation paper on review of fees charged by the Court of Session, Sheriff Courts, Office of the Public Guardian, Accountant of Court and High Court (2008), para 1.1.
} 
to pay for this. Consequently, fees are charged rather than the costs being funded from general taxation... ${ }^{45}$

The second theme is a repeated commitment to ensuring that access to justice is maintained for those who cannot afford to go to court. ${ }^{46}$ The tension between FCR and maintaining access to justice is managed (at least in the view of successive Scottish Governments) by a fee exemption regime. Under this regime, those in receipt of either civil legal aid or certain means tested benefits are not required to pay court fees.

Third, the effects of FCR on access to justice for those ineligible for the fee exemption regime (i.e. people whose circumstances place them above the thresholds for civil legal aid or means tested benefits) are portrayed as minimal. Scottish Governments have repeatedly asserted that court fees make up a small proportion of the overall costs of civil litigation. ${ }^{47}$ The assumption behind this repetition appears to be that because court fees constitute a low proportion of overall costs, they cannot be prohibitive of themselves.

To evidence this assertion, particular reliance is made on a 2007 study commissioned by the Ministry of Justice which purports to show that the cost of court fees plays a minor role in the decision to go to court. ${ }^{48}$ This research was also referred to approvingly in the Report of the Scottish Civil Courts Review in 2009 (the "Gill Review”). ${ }^{49}$ We critique the 2007 study below.

In passing, it can be noted that FCR is not solely a matter for the court system, and many public services are facing a similar push towards FCR. For example, a recent consultation regarding fees connected with bankruptcy proceedings was preloaded with the declaration "All government Bodies are asked to work to the general principle of full cost recovery, where the users and those who benefit from the service the Agency provides meet the costs associated with those services." 50 That being the case, when it came to responding to that consultation exercise the Accountant in Bankruptcy noted that "Bankruptcy numbers, and income from fees, will... be very dependent on the economic cycle - so that seeking full cost recovery for each and every individual year would mean regular and significant changes in fee levels” and further noting that "It is accepted that the aspiration to achieve full cost recovery is just that - a

\footnotetext{
${ }^{45}$ Scottish Government, Fees charged by the Court of Session, Accountant of Court, Sheriff \& Justice of the Peace Courts, High Court, Office of the Public Guardian, personal injury court and the Sheriff Appeal Court: Consultation Paper (2015), para 12.

${ }^{46}$ Scottish Executive, 2001 consultation, para 2 and Scottish Court Service, 2008 consultation, para 2.2.

${ }^{47}$ Scottish Court Service, 2008 consultation, para 2.2.5; Scottish Government, 2015 consultation, para 13; Scottish Government, Consultation on Scottish Court Fees (2016) 7; Scottish Government, Equality Impact Assessment Record: Consultation on Scottish Court Fees 2018-2021 (Court of Session, High Court of Justiciary, Sheriff Appeal Court, Sheriff Courts including Sheriff Personal Injury Court, Justice of the Peace Courts and Office of the Public Guardian) (2018) 6.

${ }^{48}$ Scottish Court Service, 2008 consultation para 2.2.5 and Scottish Government, 2015 consultation para 13.

49 Brian Gill, Report of the Scottish Civil Courts Review - Volume 2 (2009), ch 14, para 165, available at https://www.scotcourts.gov.uk/docs/default-source/civil-courts-reform/report-of-the-scottish-civil-courtsreview-vol-2-chapt-10---15.pdf?sfursn=4.

50 See https://www.aib.gov.uk/sites/default/files/2017_fees_consultation_final.pdf. Thanks to Donna McKenzie Skene for drawing this to our attention. Consider also the costs of land registration and the Final Business and Regulatory Impact Assessment to The Fees in the Registers of Scotland Amendment Order 2010, which noted Registers of Scotland's obligation to recover the full operating costs of its services (para 2), at http://www.legislation.gov.uk/ssi/2010/404/pdfs/ssien_20100404_en.pdf.
} 
principle with limits in practice". ${ }^{51}$ That sets something of a general critique of FCR. A courtspecific critique now follows.

\section{CRITIQUING FULL COST RECOVERY}

FCR can be criticised for a number of reasons. Chief amongst these is its effect on the ability of individuals to afford access to the civil justice system. Further, FCR's rationale is based on several questionable propositions.

\section{(1) Effect of FCR on access to justice}

The House of Commons Justice Committee has warned that the introduction of FCR requires "particular care and strong justification" 52 due to its potential impacts on access to justice. In its analysis, the introduction of fees to UK Employment Tribunals had a "significant adverse impact on access to justice for meritorious claims”. ${ }^{33}$

Access to justice has been alluded to already, but it now falls to be analysed in the context of FCR specifically. It is not the place of this article to seek to define access to justice, ${ }^{54}$ but it might be useful to set out what it means in broad terms. As a general starting point, Cornford suggests the paradigm of access to justice "entails a right of equal access to legal assistance for every citizen". ${ }^{55}$ When it comes to access to justice in Scotland, the story invariably starts in the fifteenth century with the Poor's Roll, ${ }^{56}$ which the late Lord Bingham described as "the world's first statutory authority on legal aid for the poor". ${ }^{57}$ Recent analysis by Findlay has shed useful light on the legal profession's history of pro bono work in applying this system, ${ }^{58}$ and further legal aid provision can be tracked from the introduction of the welfare state in the aftermath of World War II. ${ }^{59}$ But providing and supporting access to representation is not quite

\footnotetext{
51 https://www.aib.gov.uk/sites/default/files/aib_-_policy_development_-_fees_regulations_2018_consultation response - april 2018 2.pdf (8).

${ }^{52}$ House of Commons Justice Committee, Courts and tribunals fees (HC 167) (UK Parliament, 2016), para 46.

53 Ibid, para 69.

${ }^{54}$ See generally D B Walters, "Legal aid, access to justice and the rule of law" in D L Carey Miller and D W Meyers (eds) Comparative and historical essays in Scots law: a tribute to Professor Sir Thomas Smith QC (1992) 117; Genn and Paterson, Paths to Justice Scotland; A Paterson, Lawyers and the Public Good: Democracy in Action? The Hamlyn Lectures, 62nd Series (2011); and E Palmer, T Cornford, A Guinchard and Y Marique (eds), Access to Justice: Beyond the Policies and Politics of Austerity (2016). In passing, it can be noted that there is an Access to Justice Act 1999, but that fails to provide an authoritative definition.

${ }^{55}$ A Cornford, “The Meaning of Access to Justice”, in Palmer et al (eds), Access to Justice 27 at 39. Cf Paterson, Lawyers and the Public Good, 60.

56 This provides, "gif there bee onie pure creature that... can nocht, nor may nocht follow his cause the King, for the lufe of god sall ordane that Juge befor quham the cause suld be determyt purvey and get a lele and a wyse advocate to follow sic pur creaturis cause. And gif sic cause be obteynt the wranger sall assyth bath the party scathit and the advocatis costis and travale.” Ordinance of the Parliament of Perth passed on 12 March 1424, APS II, 1424, p8 (c. 24), quoted in Walters, “Legal aid, access to justice and the rule of law” 152.

${ }^{57}$ Bingham, The Rule of Law 87.

58 J Findlay, Legal Practice in Eighteenth-Century Scotland (2015) ch 6. See also some contemporary analysis in also some contemporary discussion about this in Bell's Dictionary (1838) 749, and in W Dunlop Treatise on the Law of Scotland Relative to the Poor 2nd edn (1828). Thanks to Adelyn Wilson for drawing these to our attention.

${ }^{59}$ Through the Legal Aid and Solicitors (Scotland) Act 1949. As a result of the Legal Aid (Scotland) Act 1986, the Scottish Legal Aid Board came into being in 1987. Relevant history is explained on the Board's website, accessible at https://www.slab.org.uk/about-us/who-we-are/history/.
} 
the same thing as setting court fees that price people out of the system. ${ }^{60}$ Requiring court users to directly pay the costs of civil justice has the potential to make the courts inaccessible to certain individuals. Court fees may have an indirect discriminatory effect on groups with below average incomes and personal wealth. The Equality and Human Rights Commission has raised concerns that disabled people, ethnic minorities and women may be disproportionately affected by the rises in court fees. ${ }^{61}$

The fee exemption regime goes some way to mitigating these reservations. However, there are concerns surrounding the creation of a 'middle income trap' ${ }^{62}$ This refers to the situation where those on low incomes retain access to justice through an exemption from court fees, and high earners can afford raised fees. Those on middle incomes are said to be 'trapped' between the two - ineligible for exemptions yet unable to afford the new fees. The Faculty of Advocates has noted the "very low" thresholds for fee exemptions, which leaves a "very substantial proportion of Scots" ineligible. ${ }^{63}$

As stated, the Scottish Government has relied on a 2007 Ministry of Justice-commissioned study ${ }^{64}$ for the proposition that cost of court fees is a minor factor for individuals considering to go to court. The study - titled 'What's cost got to do with it?' - sought to examine the effect that court fees had on court users accessing the courts. It used several methods including a literature review, group discussions with court users who had paid their own fees and personal injury representatives and telephone surveys with court users who had paid their own fees.

In terms of the Scottish Government's reliance on the study as evidence of the non-significance of court fees, two features of the research bring this belief into question.

First, the study provides evidence that court fees can affect the decision to go to court (albeit for a minority of the court users involved in the study). During the study, individuals were asked whether their decision to proceed to court would have been affected if court fees had been higher. $69 \%$ said that it would not make a difference; $18 \%$ said that it would have made a difference, $10 \%$ said that it was dependent on the amount of the increase and $3 \%$ felt unable to answer the question. ${ }^{65}$

The study also asked individuals to rate the impact that incremental court fee increases would have on their decision to progress to court. Participants were asked what impact having court fees increase by set amounts would have on their decision to go to court. The fee increases tested were $£ 10, £ 50, £ 100, £ 150, £ 200$ and $£ 300$. The study found that:

Overall, the number of individuals who would definitely progress a claim to court decreases by roughly $10 \%$ with each cost increment up to an increase of $£ 100$ in total... So, if price were to increase by $£ 10, £ 50$ and $£ 100$, those likely to definitely go to court would decrease by $10 \%$ for each of the 3 price increases. ${ }^{66}$

\footnotetext{
${ }^{60}$ Consider S Peers, "Europe to the Rescue? EU Law, the ECHR and Legal Aid”, where he notes legal aid in EU countries [then including the UK] "takes two forms: support for the costs of a lawyer, and exemption from court fees”, in Palmer et al (eds) Access to Justice 53 at 53.

${ }^{61}$ Equality and Human Rights Commission Consultation Response (2016) 7.

62 Citizens Advice Scotland 2016 Court Fees Consultation Response (2016) 6.

${ }^{63}$ Faculty of Advocates Consultation Response (2016) 12.

${ }^{64}$ UK Ministry of Justice, What's cost got to do with it? The impact of changing court fees on users (UK MOJ, 2007).

65 Ibid, 49.

66 Ibid, 52.
} 
At the maximum price increase of $£ 300$, it found that only 6 in 10 participants would still definitely go to court. ${ }^{67}$ The study therefore suggests a significant minority of court users could be deterred from accessing the court by fee increases.

Second, the methodology of the research means that the study cannot be relied upon for the proposition that cost is a small factor for individuals considering to go to court. The research surveyed court users who had started either family or civil court proceedings in the period August 2005 to July 2006 at a court in England and Wales and paid their own fees.

The study surveyed the views of those whose cases were already in court, and who had already paid fees to access civil justice - it did not survey those who were considering to go to court. This is an important distinction. There may be many individuals who had already been deterred from going to court by the court fees which existed at the time of the study. ${ }^{68}$ Given this selection of participants, it is open to question whether the study provides any useful findings in relation to the effect of court fees on those considering going to court.

Overall then, the extent to which court fees in Scotland deter individuals considering to access civil justice is unknown. The study provides evidence that - even of those who are able to pay court fees - increasing court fees would have a detrimental effect on a significant minority. There is sufficient evidence to question the Scottish Government's position that such effects are minimal.

\section{(2) The rationale for FCR}

The view of the Scottish Government is that the civil courts provide a private dispute resolution service whose benefits largely accrue to the parties involved. FCR is justified as removing a subsidy. Underpinning this rationale are two notions: that access to civil justice is an optional commodity and that the majority of the benefits of civil litigation go to the parties involved. These shall be critiqued in turn.

\section{(i) Access to civil justice as an optional commodity}

Wilmot-Smith has argued that passing the costs of the civil justice system to its immediate users transforms it from a 'public service', to 'a service, available for public use'. ${ }^{69}$ Under FCR, an individual who raises court proceedings 'purchases' their entitlement to a judgement from the court through the payment of a court fee ${ }^{70}$ - and the courts are only accessible to those who are able to pay court fees (unless eligible for an exemption).

Access to civil justice effectively becomes a commodity or a consumer purchase option which can be acquired, rather than a universal entitlement to be enjoyed equally by all. The notion that justice can be bought and sold conflicts with the concept of justice itself, which requires that both sides and their arguments are heard, independently of their ability to pay. ${ }^{71}$

\footnotetext{
${ }^{67}$ Ibid, 52.

${ }^{68}$ For general discussion and a Scottish study of the factors that might keep people away from court, see Genn and Paterson, Paths to Justice Scotland.

${ }^{69}$ F Wilmot-Smith, “Court Cuts” (2015) 37(15) London Review of Books 10.

${ }^{70}$ Civil Justice Council 2002, para 7.4.

${ }^{71}$ A Weale, "Principles of Access: Comparing Health and Legal Services”, in Palmer et al (eds), Access to Justice 41 at 51 .
} 
In a society where rights are set out in law, it is difficult to imagine how rights could be effectively realised without recourse to judicial enforcement. Without access to the courts, rights can be neglected - leaving those with wealth and political power free to exploit the poor and the weak. ${ }^{72}$ If it is accepted that legal rights which an individual is unable to enforce through the courts are of little worth, access to civil justice can only be regarded as optional if the same attitude is taken towards realising legal rights. Access to civil justice is a precondition to the enjoyment of legal rights.

Access to civil justice is better understood as a human right. This view is supported by a range of international human rights agreements which recognise the right of access to justice in various forms, and in relation to numerous topics. ${ }^{73}$ Civil justice is a constitutional fundamental and a social necessity; it is not a product which an informed consumer can choose at will. FCR is an inappropriate market solution that commoditises access to a public service which has important social functions.

\section{(ii) The civil justice system is a private dispute resolution service}

An initial point relates to any characterisation of any public service as leading to private benefits. Part of the rationale for providing health care and education which is free at the point of use, for example, is that - despite individuals gaining discrete personal assistance as a result - such services also provide collective social benefits. Similarly, the civil justice system provides a combination of individual and public benefits. There are broad benefits from having a literate, educated and healthy populace - and it can also be contended that collective benefits accrue from individuals having access to an effective and respected way of resolving disputes. ${ }^{74}$

It is true that litigation can create excludable private benefits for the parties involved, such as an award of damages for personal injury. ${ }^{75}$ However, it is a misconception that only the immediate parties to litigation gain any benefits. The idea that the civil justice system is a private dispute resolution service for solving problems between individuals, with little wider social benefit, is demonstrably fictitious.

Society draws a number of benefits from civil justice. Litigation allows for enforcement of the rights and rules which are key to a healthy and just society such as human rights, employment laws and environmental regulation. The public vindication of such legal rights plays a critical role in ensuring that these legal frameworks have life outside the legislature. Litigation clarifies and decides the law for the community, ${ }^{76}$ helps to maintain social order by resolving disputes peacefully ${ }^{77}$ and can play a role in preventing harm. ${ }^{78}$

\footnotetext{
${ }^{72}$ F Wilmot-Smith, “Necessity or Ideology?” (2014) 36(21) London Review of Books 15-17.

${ }^{73}$ E.g. Universal Declaration of Human Rights 1948, Article 8; European Convention of Human Rights 1950, Article 13; International Covenant on Civil and Political Rights 1966, Article 2(3); Convention on Access to Information, Public Participation in Decision-Making and Access to Justice in Environmental Matters 1998, Article 9; Charter of Fundamental Rights of the European Union 2000, Article 47.

${ }^{74}$ Civil Justice Council, para 4.2.

${ }^{75}$ S Rares, “Is Access to Justice a Right or a Service?”, speech given at Access to Justice - Taking the Next Steps Symposium, Melbourne (26 June 2015), available at http://www.fedcourt.gov.au/digital-law-library/judgesspeeches/justice-rares/rares-j-20150626.

${ }^{76}$ Ibid.

${ }^{77}$ H Genn, “Understanding Civil Justice”, in M Freeman (ed), Law and Public Opinion in the 20th Century (1997) 162.

${ }^{78}$ Wilmot-Smith, “Court Cuts”.
} 
Litigation provides useful training for the lawyers and judges involved and can result in the disclosure of facts which are important for public health, government integrity and "the general support of peace and order". ${ }^{79}$ The belief that claims of injustice will be taken seriously and addressed by an impartial adjudicator is said to lessen alienation and strengthen community cohesion, ${ }^{80}$ and the courts reinforce dominant social and economic values. ${ }^{81}$

Hazel Genn has explained that the famous case of Donoghue $v$ Stevenson ${ }^{82}$ demonstrates the public benefits of civil litigation:

The case effectively transformed the law. Whatever view is taken of the decision, the case established protection for consumers, created an incentive for those who create risks to take care and the possibility of redress for those harmed by negligent actions. In this way the common law has developed on the back of private and business disputes and thousands of cases have been settled in its wake. ${ }^{83}$

It is important to remember that civil courts do not adjudicate solely in disputes between private individuals. They have important constitutional functions also. ${ }^{84}$ In exercising their public law jurisdiction, the civil courts are critical to maintaining the rule of law.

On most understandings of the rule of law, the Executive should act within its legal powers. To ensure this, the state must provide its citizens access to the courts to police the legality of executive acts through the supervisory jurisdiction of judicial review. By forcing the state to release information and provide remedies, civil litigation can constitute a "democracyenhancing practice". ${ }^{85}$ This restricts the arbitrary, self-interested use of public power and promotes good government. Recent cases such as Miller ${ }^{86}$ and UNISON produced decisions on critical constitutional issues which clarified the law and provided socially valuable precedents; appropriately enough, UNISON also clarified the public benefits that flow from the enforcement of rights conferred by Parliament, ${ }^{87}$ a point returned to below.

\section{CHALLENGING FULL COST RECOVERY}

The previous section critiqued FCR in theory. We now consider ways in which an inaccessible justice system could be challenged in practice through the courts, primarily through human rights but also considering Scots common law. ${ }^{88}$

\footnotetext{
${ }^{79}$ E Thornberg, "Reaping what we sow: anti-litigation rhetoric, limited budgets, and declining support for civil courts” (2011) 30(1) Civil Justice Quarterly 74 at 81.

${ }^{80} \mathrm{H}$ Genn, "Why the privatisation of civil justice is a rule of law issue" speech given at London (19 November 2012), 17. Available at https://www.ucl.ac.uk/laws/sites/laws/files/36th-f-a-mann-lecture-19.11.12-professorhazel-genn.pdf (accessed 19/01/2019).

${ }^{81}$ Genn, Judging Civil Justice 18.

821932 SC (HL) 31.

${ }^{83}$ Genn, Judging Civil Justice 20-21.

${ }^{84}$ See R E Lee's discussion on this, in, “The American Courts as Public Goods: Who Should Pay the Costs of Litigation?” (1985) 34 Cath. U. L. Rev. 267 at 274-276.

${ }^{85}$ Genn, Judging Civil Justice 23.

${ }^{86} R$ (on the application of Miller and another) $v$ Secretary of State for Exiting the European Union [2017] UKSC 5.

87 [2017] UKSC 51, para 102.

${ }^{88}$ At the time of writing, another route of challenge would be that FCR may contravene certain provisions of EU law (see discussion in UNISON, paras 105-117). However, this article is not intended to be an exhaustive
} 


\section{(1) ECHR Article 6(1)}

\section{(a) Jurisprudence on the right to a court under Article 6(1)}

Scottish legislation - including secondary legislation on court fees - must comply with the European Convention on Human Rights (ECHR). ${ }^{89}$ Article 6 of the ECHR protects the right to a fair hearing, and Article 6(1) ${ }^{90}$ of the ECHR has been interpreted by the European Court of Human Rights (ECtHR) as providing for a 'right to a court' to assert civil rights. ${ }^{91}$

The ECtHR has found that the right of access to a court must be practical and effective. ${ }^{92}$ However, the right is not absolute and limitations may be imposed by a State. In the ECtHR's jurisprudence, this is justified because the right of access "by its very nature calls for regulation by the State” 93 - and Article 6(1) leaves a contracting state a 'margin of appreciation' in the means to be used in ensuring this right.

Although states can limit the right, the ECtHR requires that any limitations which are imposed must not impair the essence of the right. ${ }^{94}$ Additionally, a limitation will not be Article 6(1) compatible unless it pursues a 'legitimate aim' and there is a 'reasonable relationship of proportionality' to the aim sought. ${ }^{95}$

The ECtHR has considered the consistency of court fees with the Article 6 right to a fair hearing in several cases. It has declared court fees to violate the Article 6(1) right of access to a court in a number of decisions. ${ }^{96}$ Overall, the ECtHR is not particularly stringent in its supervision of court fees. ${ }^{97}$ It gives a margin of appreciation to States, and when considering breaches it applies an individualised assessment as to whether fees are compliant, examining the applicant's ability to pay. ${ }^{98}$

The jurisprudence on this issue does not allow for an exact demarcation between fees which would be permissible and those which would violate Article 6(1). Instead, the cases demonstrate that at least five factors are considered by the ECtHR as indicative of a violation.

consideration of the potential legal mechanisms by which to litigate against FCR. In consideration of this, and in light of the uncertainty of the status of EU law in Scotland post-Brexit, we have limited our analysis accordingly. ${ }^{89}$ Scotland Act 1998, s 29(2)(d) and s 57(2).

${ }^{90}$ Article 6(1) states that, "In the determination of his civil rights and obligations..., everyone is entitled to a fair and public hearing within a reasonable time by an independent and impartial tribunal established by law...”. See generally J Murdoch, Reed and Murdoch: Human Rights Law in Scotland (2017) ch 5.

${ }_{91}$ Golder v the United Kingdom (1979-80) 1 E.H.R.R. 524, paras 34-35.

${ }^{92}$ Bellet v France, (23805/94) (ECHR, 4 December 1995), para 36.

93 Podbielski and PPU Polpure v Poland (39199/98) [2005] ECHR 543, para 62.

${ }^{94}$ De Geouffre de la Pradelle v France (12964/87) [1992] ECHR 76, para 28.

${ }^{95}$ Kreuz v Poland (28249/95) 11 B.H.R.C. 456, para 55.

96 Kreuz; Podbielski; Kniat v Poland (71731/01) (ECHR, 26 July 2005); Weissman and Others $v$ Romania (63945/00) ECHR 2006-VII; TeltronicCATV v Poland (48140/99) [2006] ECHR 21; Stankov v Bulgaria (25820/07) [2015] ECHR 276; Kordos v Poland (26397/02) (ECHR, 26 May 2009) and Georgel and Georgeta Stoicescu v Romania (9718/03) [2011] ECHR 1193.

${ }^{97}$ M Kuijer, 'Article 6 ECHR: Access to Court' (Bulgarian Lawyers for Human Rights, 2006), available at blhr.org/media/documents/Access_to_court_1.doc.

98 Podbielski, para 64 and Weissman, para 37. 
The first (and clearest) factor is that a person has been unable to pursue their civil claim due to being unable to pay the court fees. ${ }^{99}$ In Kreuz $v$ Poland the fact that a court fee was equivalent to the national annual salary at the time of the litigation was indicative that it was not affordable for the applicant. ${ }^{100}$

It is not necessary for the fees to have prevented a person from pursuing his/her claim. In Stankov $v$ Bulgaria, fees imposed after the conclusion of litigation were deemed capable of violating Article 6(1), because the fees amounted to 90\% of the compensation which had been awarded to the applicant in a claim against the state for wrongful detention. ${ }^{101}$

Second, the conduct of the relevant judicial authorities can be relevant. For example, a refusal by national judicial authorities to accept an applicant's claim to be unable to pay his/her court fees, ${ }^{102}$ a failure by the judicial authorities to accurately assess an applicant's financial situation, ${ }^{103}$ an assessment by the judicial authorities that an applicant with limited means is able to pay a court fee, the payment of which would have a detrimental effect on the applicant's ability to "build her future and secure her and her minor children's basic needs" ${ }^{104}$ after a divorce and a failure by the judicial authorities to allow an applicant to pay either a reduced court fee ${ }^{105}$ or pay a fee in instalments ${ }^{106}$ have all been deemed as supportive of an Article 6(1) violation.

The way in which fees are administered is the third factor. Fees imposed at the outset of proceedings have been deemed by the ECtHR to have a more significant effect, because they can prevent a claim from being heard by a national court. ${ }^{107}$ However, (as mentioned) Stankov $v$ Bulgaria showed that fees imposed after the conclusion of litigation are also capable of violating Article 6(1).

Fourth, the aim of the system of court fees is relevant. The ECtHR has repeated that restrictions which are of a purely financial nature and unrelated to the merits of an appeal or its prospects of success, "should be subject to a particularly rigorous scrutiny". ${ }^{108}$

In Reuther $v$ Germany, ${ }^{109}$ an unsuccessful claim of an Article 6(1) violation, the applicant's claim in the German courts was deemed to have little merit. The applicant in Reuther had been deterred from accessing court by a fee. The ECtHR held that it had never ruled out the possibility that the interests of the "fair administration of justice" 110 (i.e. deterring unmeritorious claims) may justify the imposition of a financial limitations on the right to a court.

\footnotetext{
${ }^{99}$ Kreuz, para 66; Podbielski, para 65; Weissman, paras 38-40; TeltronicCATV, para 50 and Georgel and Georgeta Stoicescu, para 69.

${ }^{100}$ Kreuz, para 62.

101 Stankov, paras 51, 53 and 54.

102 Kreuz, para 64.

103 TeltronicCATV, paras 53-59.

${ }^{104}$ Kniat, para 44. See also the ECtHR's reference to an applicant's need to secure her "basic needs" in the context of court fees in Kordos, para 36.

${ }^{105}$ Kniat, para 43.

106 Podbielski, para 67.

107 Weissman, para 42; TeltronicCATV, para 61 and see discussion in Georgel and Georgeta Stoicescu at para 69.

108 TeltronicCATV, para 61; Podbielski, para 65; Kordos, para 33.

${ }^{109}$ Reuther v Germany (74789/01) ECHR 2003-IX.

${ }^{110}$ Reuther, para 2.
} 
In this vein, in Podbielski and PPU Polpure v. Poland the ECtHR found that because the aim of a court fee was the State's interest in deriving income from fees rather than protecting the other party from irrecoverable legal costs or protecting the system of justice against an unmeritorious appeal by the applicant - this was a factor indicative of a violation of Article $6(1) .^{111}$

Finally, the ECtHR has examined the nature of the claim and the applicant's conduct throughout the claim. Having a claim which is not frivolous or unmeritorious counts in an applicant's favour, ${ }^{112}$ and the court requires "particular diligence" ${ }^{113}$ by national authorities in cases which concern an applicant's civil status. In Zubac v Croatia the fact that an applicant incurred higher court fees as a result of her conduct during the case counted against her claim of an Article 6(1) violation. ${ }^{114}$

\section{(b) Raising an Article 6(1) claim in Scotland}

Article 6 issues have been frequently raised in the Scottish Courts, and its use has led to high profile changes to Scots law such as the introduction of a statutory right of access to legal advice for suspects being questioned by the police following the UK Supreme Court's decision in Cadder. ${ }^{115}$ However, the right to a court has been raised infrequently in the Scottish Courts, and only one successful challenge has been made on this basis.

In Kelly $v$ Gilmartin's Executrix ${ }^{116}$ the Court of Session was not persuaded by the argument that the right to a court should lead to an interpretation of the Prescription and Limitation (Scotland) Act 1973 that would extend the period of negative prescription for a personal injury claim. Apollo Engineering Limited $v$ James Scott Ltd saw an Extra Division of the Court find that a rule which required a company to be represented in court only by an advocate or a solicitor with a right of audience, and denied a director or employee the right to represent the company, was compliant with Article $6 .{ }^{117}$ Similarly, orders by sheriffs that litigants find caution of $£ 10,000^{118}$ and $£ 3,000^{119}$ to proceed with their cases and the provisions of the Vexatious Actions (Scotland) Act 1898 have all been upheld as compliant with the right to a court derived from Article 6.

The only instance of the Scottish Courts declaring a violation of Article 6(1) in relation to the right to a court arose in the case of $S v$ Miller (No 2), ${ }^{120}$ due to the absence of legal aid to pay for the legal representation of a child in a children's hearing. The issue of court fees affecting the right to a court does not appear to have been raised in the Scottish Courts.

\footnotetext{
${ }^{111}$ Podbielski, para 66.

112 TeltronicCATV, para 60.

113 Kniat, para 41.

${ }^{114}$ Zubac v Croatia (40160/12) [2018] ECHR 306, para 120.

115 Cadder v HM Advocate [2010] UKSC 43, which led to the introduction of the Criminal Procedure (Legal Assistance, Detention and Appeals) (Scotland) Act 2010.

1162004 SC 784.

117 [2012] CSIH 4; 2012 SC 282. In the appeal that followed, the UK Supreme Court noted its concerns (albeit without reference to Article 6), stating at paragraph 30 that “...there may be grounds for thinking that the rule which disables a company from being represented other than by counsel or a solicitor with a right of audience needs to be re-examined”. Apollo Engineering Limited v James Scott Limited [2013] UKSC 37.

118 William Dow (Potatoes) Ltd v Dow 2001 SLT (Sh Ct) 37.

${ }^{119}$ Cairns v. Strathclyde Police [2004] ScotSC 25 (2 April 2004, reference A116/03) available at http://www.scotcourts.gov.uk/search-judgments/judgment?id=c9c986a6-8980-69d2-b500-ff0000d74aa7. 1202001 SLT 1304.
} 
Careful consideration of the five factors discussed above would be required to raise a successful legal challenge against court fees in Scotland, on the basis of an Article 6(1) violation. For the purposes of such a challenge, having been impeded from going to court by fees would clearly strengthen a litigant's case. In this regard, evidence may be required to demonstrate that either the litigant did not have access to the necessary funds to pay his or her court fees. If this is not possible, a litigant could demonstrate that although such funds may have been notionally available, their use would have threatened other essential household expenditure or would have put the litigant at risk of falling below an acceptable standard of living. ${ }^{121}$

Several features of the system of the administration of court fees in Scotland would assist a litigant. The fact that fees are imposed at the outset of litigation, and that they are unrelated to the merits of cases being taken, would count in a litigant's favour. There might also be casespecific factors that could assist an applicant's case, such as the pursuit of a strong legal claim or the conduct of the judicial authorities, if relevant.

If a litigant was able to successfully persuade a court that court fees had violated their right of access to a court, the question of appropriate remedies would then arise. Given the individualised nature of the assessment which is outlined in the ECtHR's jurisprudence on this subject, a successful legal challenge of this sort may not result in the revocation of FCR in its entirety. Any such claim, if successful, might only result in a declaration that a violation occurred for the particular litigant (albeit this would depend on how the case was argued and other variables). On the other hand, if a litigant was able to provide evidence that the effect of the fees system on the right to a court affected a significant proportion of the population of which (s)he was effectively representative, then this may persuade a court to disapply or declare that the implementing legislation is not law.

\section{(2) Challenging FCR at common law}

Our final point of discussion is whether an inaccessible feeing system could be challenged on a basis other than the ECHR, through an underlying commitment to access to justice. (For the purposes of this assessment we would assume that any such system was introduced after appropriate consultation and no procedural or administrative law challenge could be made.) ${ }^{122}$ As has already been noted, the traditional starting point for notions of access to justice in Scotland is the $15^{\text {th }}$ century Poor's Roll, with analysis then working forward from there focussing on the ways in which indigent litigants have been offered support to conduct their cases through the years. This shows that Scots law has long afforded means by which people can find support while litigating, but would Scots law allow a challenge to be brought directly against a court fee contained in a legal instrument that was otherwise properly made?

In the recent UNISON case the UK Supreme Court held that the Employment Tribunals and the Employment Appeal Tribunal Fees Order $2013^{123}$ was an unlawful exercise of the Lord Chancellor's powers under section 42(1) of the Tribunals, Courts and Enforcement Act

\footnotetext{
${ }^{121}$ For example with reference to the minimum income standards which have been developed by the Joseph Rowntree Foundation, and which were referred in UNISON, paras 51-53 and 94.

${ }^{122}$ Consider $R$ (on the application of The Law Society) $v$ The Lord Chancellor [2018] EWHC 2094 (Admin), where "another claim for judicial review of a decision by the Lord Chancellor to reduce the amount of money made available as legal aid for defending people accused of crimes” in England and Wales was successful, owing to a flawed consultation exercise.

123 SI 2013/1893.
} 
2007. ${ }^{124}$ This was the case because the prescribed fees interfered unjustifiably with the right of access to justice under (English) common law, and also EU law (to the extent that any rights curtailed by the fees were rights contained in EU law).

Whilst it was a Scottish justice, Lord Reed, who provided the unanimous judgment in that case (augmented by a contribution by Lady Hale on discrimination), ${ }^{125}$ the access to justice lessons for Scots common law from this case can only be drawn with suitable caveats about the transferability of the judgment.

Lord Reed led a lengthy discussion on the "constitutional right of access to the courts", 126 where he explained the ways in which the English Courts have delineated this principle with reference to a number of significant cases. ${ }^{127}$ All of the features of this part of the judgement are indicative of its particular applicability to England. In particular, in his discussion on the legal authorities supportive of the existence of a right of access to the courts, Lord Reed made reference to exclusively English cases, ${ }^{128}$ quoted from the Magna Carta of 1215 (a constitutional text on which MacQueen recently commented, "the unrepealed chapters... are not, and never have been, part of the law of Scotland") ${ }^{129}$ and discussed contributions by English legal writers (Edward Coke and William Blackstone). ${ }^{130}$ When these factors are combined with the fact that the discussion was preceded by the heading, "Is the Fees Order unlawful under English law?”, ${ }^{131}$ the likelihood is that its direct transferability to Scots law will be limited.

On the other hand, UNISON will have some influence on the Scottish courts. The legislation which underpins the Supreme Court itself provides that, "A decision of the Supreme Court on appeal from a court of any part of the United Kingdom, other than a decision on a devolution matter, is to be regarded as the decision of a court of that part of the United Kingdom." "132 The question of what degree of precedent is to be accorded to such decisions of the UK Supreme Court (and its predecessor the House of Lords) in the Scottish Courts is a topic in itself, the answer to which is context-dependent. ${ }^{133}$ Given the above discussion, the decision could be expected to be persuasive on the Scottish Courts, but cannot automatically be treated as binding. It might further be expected that the Scottish courts will look to Scotland's own historical legal texts and traditions in any determination of the existence of a common law right of access to justice; ${ }^{134}$ the route to a decision might be different and as yet untested, but the drive to reach a similar decision would be great.

\footnotetext{
124 [2017] UKSC 51.

125 [2017] UKSC 51, paras 121-134.

126 [2017] UKSC 51, para 66.

127 [2017] UKSC 51, paras 66-85.

${ }^{128}$ Lord Reed also makes reference to the Scottish cases Donoghue v Stevenson and Dumfries and Galloway Council $v$ North [2013] UKSC 45 (para 69), but these references were intended to provide examples of cases with wider significance beyond the parties which were involved in the litigation, rather than the existence of the right of access to the courts.

${ }^{129}$ H L MacQueen, “Magna Carta, Scotland and Scots law” (2018) 134 LQR 94 at 116.

130 [2017] UKSC 51, para 75.

131 [2017] UKSC 51, the title precedes para 65.

132 Constitutional Reform Act 2005, s 41(2).

133 See for example, J Henderson, "English Cases as Scots Authorities" (1900) 12 Jur. Rev. 304 and N Walker, Final Appellate Jurisdiction in the Scottish Legal System (Scottish Government, 2010), appendix III, available at https://www2.gov.scot/Publications/2010/01/19154813/0.

${ }^{134}$ E.g., the Poor's Roll, discussed above.
} 
That being said, useful analysis of the case has already taken place from a Scottish perspective. ${ }^{135}$ Further, the Scottish Government noticeably reacted to the most recent consultation on court fees in a manner that seemed concerned to portray its feeing arrangements as much less draconian than that which was struck down in UNISON. ${ }^{136}$ The Scottish Government also took into account relevant parts of that judgment, notably a passage where Lord Reed highlighted it was not only unaffordable fees that can prevent access to justice, but equally it could be fees that make it futile or irrational to litigate. ${ }^{137}$ All of this goes some way to show that a common law challenge is at least a consideration and could yet occur in the future, albeit (as noted below) a longer-term political strategy might be a more realistic response to FCR.

\section{E. CONCLUSION}

In UNISON, Lord Reed noted the following of the fees that were ultimately successfully challenged: "In order for the fees to be lawful, they have to be set at a level that everyone can afford, taking into account the availability of full or partial remission." 138

That statement was then highlighted by the Access to Justice Committee in the consultation response that served as an introduction to this article. The response acknowledged that Lord Reed was addressing a particular tribunal regime, but noted that it should be considered "a general statement of principle”. ${ }^{139}$ The response then concluded in the following terms:

It has been a longstanding cliché that litigation is a privilege that can only be enjoyed by the very rich or the very poor. A policy of full cost recovery only exacerbates that problem. Fee exemptions for the poorest only address one aspect of affordability. For many the cost of litigation is already a significant burden.

This article has developed the points made in that response, and introduced some further points that must be considered before any further roll out of FCR in the civil justice system is considered.

\footnotetext{
${ }^{135}$ Rose, " $R$ (on the application of UNISON) $v$ Lord Chancellor: A masterclass in the constitutional right of access to the courts". The Scottish impact of the case is discussed at 267. See also D Robertson, "Priced out of Justice" (2017) 62(9) Journal of the Law Society of Scotland 12 and S Naismith, "A Welcome Intervention" (2017) 62(9) Journal of the Law Society of Scotland 14.

${ }^{136}$ Scottish Court Fees 2018-2021: consultation analysis and Scottish Government response (2018), available at https://www.gov.scot/publications/scottish-court-fees-2018-2021-analysis-consultation-scottish-governmentresponse/pages/0/. Of note are para 22 (highlighting one respondent's submission that differentiated the Employment Tribunal fees from the regime found in the Scottish courts), para 39 (noting account had been taken of the UK Supreme Court case), and its analysis of the Supreme Court judgment at paras 52-57 (and particularly the differentiation made at para 54 between court fees in Scotland and the situation in UNISON. ${ }^{137}$ Para 76 (ibid) deserves specific study, in that the Scottish Government appeared to change course as a result of the UNISON case (and specifically para 96 of the judgment). Para 76 of the Scottish Government response is reproduced in full: "The Scottish Government has noted the comments of the Supreme Court in UNISON v Lord Chancellor in relation to low value claims. The court noted that access to justice could be prevented if the fees render the bringing of a claim 'futile or irrational' [para 96 of UNISON]. This can be the case if the court fee is such a high percentage of the value of the claim that the claim will not sensibly be brought. To that end, a low fee of $£ 20$ has been set for claims under £200. The Scottish Government now proposes to increase that level to claims under £300. This change would come into effect on 1 April 2019 to allow time for a change to be made to the rules for claiming expenses under Simple Procedure (the Sheriff Court Simple Procedure (Limits on Award of Expenses) Order 2016) so that the figure of $£ 300$ would apply there also.”

${ }^{138}$ [2017] UKSC 51, para 91.

139 Available at https://www.lawscot.org.uk/media/359439/atj-consultation-on-scottish-court-fees-20182021.pdf.
} 
The policy of FCR is part of the inheritance of devolution, and it has been enthusiastically embraced by all Scottish Governments so far. The justifications used for retaining FCR are that the civil justice system is a private dispute resolution service - the majority of the benefits of which go to the litigants directly involved, and that access to justice is protected for those who cannot afford to pay court fees by a fee exemption system.

This article has questioned these justifications. On a close reading, the evidence repeatedly cited by the Scottish Government in support of its stance that court fees have little effect on access to justice in fact suggests the exact opposite. It appears to show that increasing court fees would have a detrimental effect on a significant minority of people whose cases are already in court. Further, by surveying the views of those whose cases were in court, the study's methodology is such that it is doubtful whether the study provides any useful findings in relation to the effect of court fees on those considering going to court. The Scottish Government's position that the effects of fees are minimal rests upon shaky foundations.

Similarly, while it is correct to say that individual litigants can gain excludable private benefits from going to court, the current Scottish Government's view of the civil justice system ignores the other benefits that it provides. Access to civil justice ensures that civil rights can be enforced through the courts, helps the courts to clarify the law, resolves disputes peacefully, and is vital for democracy in policing the legality of acts of the Executive through judicial review.

We have argued that it may be feasible to challenge FCR through the courts. However, making a legal challenge could be difficult for a potential litigant for financial reasons. By necessity, a litigant would not be legally aided because if they were below the civil legal aid threshold then they would qualify for the court fee exemption and would therefore not have any complaint about having their rights affected. Such a litigant would therefore either have to pay their own legal representation to pursue such a claim, require pro bono legal representation, or attempt the claim as a party litigant. Compounding this, any such challenge would proceed through judicial review, which is a costly procedure with high court fees. There would also be a risk of liability for the expenses of the other side if the claim failed.

If the financial difficulties involved in bringing a claim can be overcome, litigation could be effective in provoking a reconsideration of FCR, either by forcing a re-write of the court fee rules following a successful challenge, or by stimulating parliamentary activity at Holyrood by drawing attention to the issue. As has been explained, the power to set court fees (or to not set court fees) is one which is exclusively enjoyed by the Scottish Ministers. For the underpinning logic of FCR to be properly challenged Scottish parliamentarians will be required to focus on an issue which, has thus far generated little debate in Holyrood. The entrenchment of FCR is such that a concerted political and legal effort will be required for the policy to be unseated. 